\title{
ANALISIS FAKTOR YANG BERHUBUNGAN DENGAN KEPATUHAN DIET GOUT ARTRITHIS PADA LANSIA
}

\author{
Andriyanto Dai ${ }^{1)}$, Sigit Mulyono ${ }^{2)}$, Uswatul Khasanah ${ }^{3)}$ \\ ${ }^{1}$ Mahasiwa Program Magister Keperawatan Fakultas Keperawatan Muhammadiyah Jakarta \\ ${ }^{23}$.Dosen Program Magister Keperawatan Fakultas Keperawatan Muhammadiyah Jakarta \\ email : andriyantodai@gmail.com
}

\begin{abstract}
Attention to non-communicable diseases is increasing because of the increasing frequency of events in the community and requires long-term handling and high costs which are a heavy burden for many people and the Government. Bout Artrithis is the second most non-communicable disease in the elderly based on the 2013 National Health Research. contagious. Lifestyle modification such as low purine diet can reduce uric acid levels and forms of preventive activities, therefore health care prioritizes promotive and preventive health support services and family support so as to increase the knowledge of the elderly and their families in carrying out dietary compliance. The purpose of this study was to determine the analysis of factors related to adherence to the diet of Gout Atrithis in the elderly at the Citizen Health Center in Benteng Palopo. The design of this study was an observational descriptive study using a cross-sectional approach. The results show that the most dominant variable and closely related to diet adherence is knowledge with the relationship of knowledge level with diet adherence showing strength, namely CoBfficients (Exp (B) 5,399). Suggestions are expected to be able to improve health education programs (advertisements in the form of posters, banners and brochures) regarding the importance of diet and understanding about diet for acidic sufferers (Exp (B) 5,399). veins and their families.There needs to be coordination with the health department related to health promotion.Bini health education is carried out in an effort to improve the knowledge of sufferers and families about urinary acidity and matters relating to the management of asamburat illness so that sufferers of uric acid are more adherent to diets that have been recommended by nurses.
\end{abstract}

Keywords: Family Support, Role of Nurses, Knowledge, Diet Compliance, Gout Artrithis. 


\section{PENDAHULUAN}

Perubahan sistem muskuluskeletal pada lansiaterjadi secara berbeda, kondisi inilah yang dapat menimbulkan berbagai pengaruh pada sistem muskuluskeletal diantaranya kadar asam urat (hiperurisemia) (Sustrani, 2009). Asam urat merupakan penyakit akibat penumpukan purin, baik karena produksi yang meningkat atau ginjal tidak mampu mengeluarkannya sehingga kristal asam urat menumpuk di persendian. Produksi yang meningkat disebabkan oleh mengkonsumsi makanan dengan kadar purin tinggi. Selain itu, karena obat-obatan, obesitas, hipertensi, hiperlipidemia, dan diabetes melitus (Wahyuningsih, 2013).

Asam urat dapat meningkat dengan cepat antara lain disebabkan karena penyimpanganmetabolisme yang umumny berkaitan dengan faktor usia dimana usia diatas 40 tahun. Asam urat meningkat pada lansia disebabkan karena perubahan gaya hidup, semakin mudahnya mendapatkan makanan siap saji seperti seafood membuat konsumsi sayuran dan serat berkurang. Asam urat pada lanjut usia jika tidak segera ditangani akan menggangu kegiatan sehari-hari, pada gout biasanya serangan terjadi secara mendadak (kebanyakan menyerang pada malam hari). Jika gout menyerang sendi-sendi yang terserang tampak merah, mengkilat, bengkak, kulit diatasnya terasa panas disertai rasa nyeri yang hebat, dan persendian sulit digerakan (Wijayakusuma, 2006). Indonesia termasuk negara berpenduduk struktur tua, karena persentase penduduk lanjut usia yang telah mencapai di atas $7 \%$ dari total penduduk. Keadaan ini berkaitan dengan adanya perbaikan kualitas kesehatan dan kondisi sosial ekonomi masyarakat. Struktur penduduk yang menua tersebut, selain merupakan salah satu indikator keberhasilan pencapaian pembangunan manusia secara nasional, sekaligus juga merupakan tantangan dalam pembangunan. (PERMENKES, 2016).

Data WHO tahun 2016, bahwa 335 juta penduduk di dunia yang mengalami Rematik. Angka prevalensi penyakit asam urat bervariasi pada Negara Barat yaitu antara 2,3-17,6 \%. Prevalensi hiperurisemia di Amerika Serikat adalah $5 \%$. Prevalensi hiperurisemia di Scotlandia sebesar $8 \%$, sedangkan di Inggris sekitar $6,6 \%$ dan meningkat setiap tahunnya. Penelitian di Taiwan tahun 2013 prevalensi penyakit asam urat sebesar 41,4 \% dan meningkat sebesar $0,5 \%$ setiap tahun. (Minaur et al., 2004, dalam Wong, 2010). Prevalensi kejadian penyakit sendi di indonesia berdasarkan diagnosis dan gejala pada tahun $201324,7 \%$ untuk provinsi yang paling tinggi prevalensi kejadian penyakit sendi yaitu Nusa Tenggara Timur dengan 33,1\% sedangkan di pulau Sulawesi, Provinsi Sulawesi Selatan Memiliki prevalensi yang paling tinggi yaitu $27,7 \%$ diikuti Sulawesi Tengah 26,7\% dan Sulawesi Barat 22,5\%.

Gout merupakan penyakit dengan ketidakpatuhan tertinggi terhadap pengobatan, selain itu ketidakpatuhan terhadap diet dan gaya hidup lebih buruk daripada ketidakpatuhan terhadap farmakoterapi. Pengaturan makan, perawatan penyakit dan pengobatan, ketiganya merupakan satu kesatuan dalam proses penyembuhan penyakit. Oleh karena itu tanggung jawab pengaturan makan bagi orang sakit bukanlah sematamata tanggung jawab seorang ahli gizi, akan tetapi merupakan tanggung jawab bersama dari ketiga unsur yang berperan dalam proses penyembuhan penyakit, yaitu dokter, perawat dan ahi gizi (Wahyuningsih, 2013). 


\section{METODE PENELITIAN}

Desain penelitian yang digunakan pada penelitian ini adalah desain penelitian deskriptif observasional dengan menggunakan metode pendekatan cross sectional, dimana variabel-variabel yang termasuk faktor risiko diobservasi sekaligus pada waktu yang sama. Populasi dalam penelitian ini adalah pasien gouth atritis yang berkunjung di Puskesmas Benteng Kota Palopo dengan jumlah 113 orang. Sampel penelitian adalah pasien Lansia dengan Gouth Artrithis dengan teknik purposive sampling, yaitu sebanyak 98 orang.

Penelitian ini dilakukan

di Puskesmas Benteng Kota Palopo. Pertimbangan pemilihan tempat penelitian karena Puskesmas ini memiliki populasi Lansia dengan Gouth Artrithis yang banyak dengan tingkat kepatuhan rendah menjalani diet purin yang telah dianjurkan oleh petugas kesehatan, sehingga memungkinkan untuk memperoleh sampel sesuai dengan kriteria inklusi.

Penelitian ini dilaksanakan dimulai dari persiapan penelitian dan proposal diajukan pada bulan Februari - Maret 2019, dan pengumpulan data dilakukan selama dua minggu, yaitu pada bulan April 2019. Dalam penelitian ini proses pengambilan dan pengumpulan data diperoleh dengan lembar observasi kuesioner meliputi karakteristik responden seperti umur, jenis kelamin, tingkat pendidikan, pengetahuan, peran perawat, dukungan keluarga dan kepatuhan diet purin.

Variabel dalam penelitian ini adalah variabel independen (bebas) yaitu pengetahuan, peran perawat dan dukungan keluarga, variabel dependennya (terikat) adalah kepatuhan diet, counfonding (perancu) yang terdiri atas umur, jenis kelamin dan tingkat pendidikan.

Proses pengumpulan data dilakukan selama kurang lebih dua minggu dengan berkoordinasi dengan pihak penanggung jawab program Lansia dan Kader.

Analisa data dilakukan secara univariat, bivariat dan multivariate dengan menggunakan uji statistik Chi-square, analisis multivariat dengan uji regresi logistic dengan menggunakan metode Backward Stepwise (Likelihood Ratio). 


\section{HASIL DAN PEMBAHASAN}

Variabel yang dianalisis univariat yaitu independen, pengetahuan, dukungan keluarga, karakteristik responden seperti usia, jenis kelamin, tingkat pendidikan. variabel dan peran perawat variabel dependen kepatuhan diet.

Tabel 1 Distribusi frekuensi responden berdasarkan umur, jenis kelamin dan pendidikan

\begin{tabular}{lcc}
\multicolumn{1}{c}{ Karakteristik } & $\mathrm{f}$ & $\%$ \\
\hline Umur & 65 & 66,3 \\
Usia Pertengahan (45-59 Tahun) & 25 & 25,5 \\
Lanjut Usia (60-74 Tahun) & 7 & 7,1 \\
Lanjut Usia Tua (75-90 Tahun) & 1 & 1,0 \\
Sangat Tua ( >90 Tahun) & & \\
\hline Jenis Kelamin & 32 & 32,7 \\
Laki-laki & 66 & 67,3 \\
Perempuan & & 64,3 \\
\hline Pendidikan & 63 & 35,7 \\
Rendah & 35 & \\
Tinggi &
\end{tabular}

Hasil penelitian menunjukkan bahwa kelamin perempuan dan sebagian besar sebagian besar menunjukkan usia lansia pada kelompok lanjut usia pertengahan. Sebagian besar responden dengan jenis responden memiliki pendidikan rendah. 
Tabel 2 Distribusi frekuensi dukungan keluarga, dukungan informasional, penghargaan, instrumental dan emosional

\begin{tabular}{lllll}
\hline Karateristik & f & \% & Mean & SD \\
\hline Dukungan Keluarga & & & & \\
& & & & \\
Tidak Baik & 55 & 56,1 & 32,42 & 5,169 \\
Baik & 43 & 43,9 & & \\
& & & 10,61 & 1,503 \\
Informasional & - & - & & \\
Tidak Baik & 64 & 65,3 & 10,48 & 1,632 \\
$\quad$ Baik & 34 & 34,7 & & \\
Penghargaan & - & - & 5,09 & \\
Tidak Baik & 46 & 46,9 & & \\
Baik & 52 & 53,1 & & \\
Instrumental & - & - & & \\
Tidak Baik & 42 & 42,9 & & \\
Baik & 56 & 57,1 & & \\
Emosional & - & - & & \\
Tidak Baik & 48 & 49,0 & & \\
Baik & 50 & 51,0 & & \\
Total & 98 & 100 & & \\
\hline
\end{tabular}

Tabel 2 menunjukkan proporsi bahwa sebagian besar memiliki dukungan keluarga tidak baik dengan rata-rata dukungan keluarga terdiri dari sebagian besar dukungan informasional tidak baik, sebagian besar dukungan penghargaan baik, sebagian besar dukungan instrumental baik dan sebagian besar dukungan emosional baik

Tabel 3 Distribusi frekuensi peran perawat

\begin{tabular}{|c|c|c|c|c|}
\hline Variabel & f & $\%$ & Mean & SD \\
\hline \multicolumn{5}{|c|}{ Peran Perawat } \\
\hline Tidak Baik & 46 & 46,9 & \multirow{2}{*}{43,45} & \multirow{2}{*}{2,971} \\
\hline Baik & 52 & 53,1 & & \\
\hline Total & 98 & 100,0 & - & - \\
\hline
\end{tabular}

Tabel 3 menunjukkan proporsi bahwa sebagian besar peran perawat baik.

Tabel 4 Distribusi frekuensi pengetahuan

\begin{tabular}{lllll}
\hline Karateristik & f & $\%$ & Mean & SD \\
\hline Pengetahuan & & & & \\
$\quad$ Tidak Baik & 59 & 60,2 & & 2,691 \\
$\quad$ Baik & 39 & 39,8 & 59,49 & \\
Total & 98 & 100,0 & - & - \\
\hline
\end{tabular}

Tabel 4 menunjukkan proporsi bahwa sebagian besar responden tingkat pengetahuan tidak baik. 
Tabel 5 Distribusi frekuensi kepatuhan diet

\begin{tabular}{lcccc}
\hline Kepatuhan Diet & f & \% & Mean & SD \\
\hline Tidak Patuh & 56 & 57,1 & 63,04 & 2.643 \\
Patuh & 42 & 42,9 & & \\
\hline Total & 98 & 100,0 & & \\
\hline
\end{tabular}

Tabel 5 menunjukkan proporsi bahwa sebagian responden dengan ketidakpatuhan diet.

Analisa bivariat pada penelitian ini dilakukan untuk melihat adanya hubungan dukungan keluarga, peran perawat dan tingkat pengetahuan terhadap kepatuhan diet.

Tabel 6 Dukungan Keluarga, Dukungan Informasional, Penghargaan, Instrumental, Emosional terhadap Kepatuhan Diet

\begin{tabular}{|c|c|c|c|c|c|c|c|c|}
\hline \multirow{3}{*}{ Variabel } & \multicolumn{6}{|c|}{ Kepatuhan Diet } & \multirow{3}{*}{$\begin{array}{c}p \\
\text { value }\end{array}$} & \multirow{3}{*}{$\begin{array}{c}\text { Ods } \\
\text { Ratio }\end{array}$} \\
\hline & \multirow{2}{*}{$\begin{array}{c}\text { Tidak } \\
\mathbf{f}\end{array}$} & \multirow{2}{*}{$\begin{array}{c}\text { Patuh } \\
\%\end{array}$} & \multicolumn{2}{|c|}{ Patuh } & \multicolumn{2}{|c|}{ Total } & & \\
\hline & & & $\mathbf{f}$ & $\%$ & $\mathbf{f}$ & $\%$ & & \\
\hline \multicolumn{9}{|l|}{ Dukungan Keluarga } \\
\hline Tidak Baik & 44 & 80,0 & 11 & 20,0 & 55 & 100,0 & 0,001 & 10.333 \\
\hline Baik & 12 & 27,9 & 31 & 72,1 & 43 & 100,0 & & \\
\hline \multicolumn{9}{|l|}{ Informasional } \\
\hline Tidak Baik & 52 & 81,3 & 12 & 18,8 & 64 & 100,0 & 0,001 & 32,500 \\
\hline Baik & 4 & 11,8 & 30 & 88,2 & 34 & 100,0 & & \\
\hline \multicolumn{9}{|l|}{ Penghargaan } \\
\hline Tidak Baik & 38 & 82,6 & 8 & 17,4 & 46 & 100,0 & 0,001 & 8,972 \\
\hline Baik & 18 & 34,6 & 34 & 65,4 & 52 & 100,0 & & \\
\hline \multicolumn{9}{|l|}{ Instrumental } \\
\hline Tidak Baik & 40 & 95,2 & 2 & 4,8 & 42 & 100,0 & 0,001 & 50,000 \\
\hline Baik & 16 & 28,6 & 40 & 71,4 & 56 & 100,0 & & \\
\hline \multicolumn{9}{|l|}{ Emosional } \\
\hline Tidak Baik & 40 & 83,3 & 8 & 16,7 & 48 & 100,0 & 0,001 & 10,625 \\
\hline Baik & 16 & 32,0 & 34 & 68,0 & 50 & 100,0 & & \\
\hline
\end{tabular}

Tabel 6 menunjukkan proporsi dukungan keluarga cenderung patuh terhadap diet jika dibandingkan dengan dukungan keluarga yang tidak baik. Hasil uji chi square $\mathrm{p}$ value $=0,001$ $<0,05$ menunjukkan adanya hubungan yang bermakna antara dukungan keluarga dengan kepatuhan diet. Penelitian ini sejalan yang dilakukan oleh Septiana Risti Amalia (2017) bahwa terdapat hubungan dukungan keluarga dengan kepatuhan diet asam urat. Keluarga harus dilibatkan dalam program diet, agar anggota keluarga yang sakit patuh pada diet yang dianjurkan. Dukungan keluarga merupakan faktor penting untuk mewujudkan kepatuhan terhadap program medis. Status kesehatan keluarga dipengaruhi oleh dukungan keluarga dalam merawat anggota keluarga yang sakit. Dukungan keluarga tersebut termasuk dukungan internal yang meliputi dukungan dari suami, istri, anak, atau saudara, yang akan membantu dalam meningkatkan kesehatan keluarga. (Friedman, 1986 dalam Setyowati \& Murwani, 
2008). Dukungan informasional yang baik akan mempengaruhi kepatuhan diet lebih besar jika dibandingkan dengan dukungan informasional yang tidak baik. Hasil uji chi square $\mathrm{p}$ value $=0,001<0,05$ menunjukkan adanya hubungan yang bermakna antara dukungan informasional dengan kepatuhan diet. Dukungan penghargaan yang tidak baik akan mempengaruhi ketidakpatuhan diet lebih besar jika dibandingkan dengan dukungan penghargaan baik. Hasil uji chi square $\mathrm{p}$ value $=0,001<0,05$ menunjukkan adanya hubungan yang bermakna antara dukungan penghargaan dengan kepatuhan diet.Dukungan instrumental tidak baik akan mempengaruhi ketidakpatuhan diet lebih besar jika dibandingkan dengan dukungan instrumental baik. Hasil uji chi square $\mathrm{p}$ value $=0,001<0,05$ menunjukkan adanya hubungan yang bermakna antara dukungan penghargaan dengan kepatuhan diet. Dukungan emosional tidak baik akan mempengaruhi ketidakpatuhan diet $83,3 \%$ lebih besar jika dibandingkan dengan dukungan emosional baik 32,0\%. Hasil uji chi square $p$ value $=0,001<0,05$ menunjukkan adanya hubungan yang bermakna antara dukungan emosional dengan kepatuhan diet.

\section{Tabel 7}

Peran perawat terhadap kepatuhan diet

\begin{tabular}{|c|c|c|c|c|c|c|c|c|}
\hline \multirow{3}{*}{ Variabel } & \multicolumn{6}{|c|}{ Kepatuhan Diet } & \multirow{3}{*}{$p$ value } & \multirow{3}{*}{$\begin{array}{c}\text { Ods } \\
\text { Ratio }\end{array}$} \\
\hline & \multicolumn{2}{|c|}{ Tidak Patuh } & \multicolumn{2}{|c|}{ Patuh } & \multicolumn{2}{|c|}{ Total } & & \\
\hline & $\mathbf{f}$ & $\%$ & f & $\%$ & $\mathbf{f}$ & $\%$ & & \\
\hline \multicolumn{9}{|l|}{ Peran Perawat } \\
\hline Tidak Baik & 35 & 76,1 & 11 & 23,9 & 46 & 100,0 & 0,001 & 4.697 \\
\hline Baik & 21 & 40,4 & 31 & 59,6 & 52 & 100,0 & & \\
\hline
\end{tabular}

Tabel 7 menunjukkan proporsi peran perawat baik akan mempengaruhi kepatuhan diet lebih tinggi jika dibandingkan dengan peran perawat tidak baik. Hasil uji chi square $\mathrm{p}$ value $=0,001<0,05$ menunjukkan adanya hubungan yang bermakna antara peran perawat dengan kepatuhan diet. Hasil penelitian ini sesuai dengan penelitian yang dilakukan Runtukahu et al (2015) menunjukkan bahwa terdapat hubungan antara peran perawat dengan kepatuhan dalam menjalankan diet dan peran petugas kesehatan yang kurang akan berpeluang 8,6 kali tidak patuh menjalankan diet dibandingkan dengan motivasi petugas kesehatan baik. Konsep Teori
Keperawatan menurut Nola J. Pender mengenai teori Health Promotion Model (HPM) sebagai kerangka untuk mengintegrasikan keperawatan dan perspektif ilmu perilaku pada faktor-faktor yang mempengaruhi perilaku kesehatan. Interaksi antara pasien dengan perawat sangat menentukan derajat kepatuhan, interaksi ini termasuk dalam faktor pendukung sesorang sebagai suatu proses individu termotivasi untuk melaksanakan komitmen dan meningkatkan kesejahteraan, mengaktualisasikan potensi kesehatan manusia salah satunya komitmen melaksanakan kepatuhan diet. 
Tabel 8 Tingkat pengetahuan responden terhadap kepatuhan diet

\begin{tabular}{|c|c|c|c|c|c|c|c|c|}
\hline \multirow{3}{*}{ Variabel } & \multicolumn{6}{|c|}{ Kepatuhan Diet } & \multirow{3}{*}{$p$ value } & \multirow{3}{*}{$\begin{array}{c}\text { Ods } \\
\text { Ratio }\end{array}$} \\
\hline & \multicolumn{2}{|c|}{ Tidak Patuh } & \multicolumn{2}{|c|}{ Patuh } & \multicolumn{2}{|c|}{ Total } & & \\
\hline & f & $\%$ & f & $\%$ & f & $\%$ & & \\
\hline \multicolumn{9}{|l|}{ Pengetahuan } \\
\hline Kurang & 42 & 71,2 & 17 & 28,8 & 59 & 100,0 & 0,001 & 4.412 \\
\hline Baik & 14 & 35,9 & 25 & 64,1 & 39 & 100,0 & & \\
\hline
\end{tabular}

Tabel 8 menunjukkan proporsi responden dengan pengetahuan baik akan mempengaruhi kepatuhan diet lebih tinggi jika dibandingkan dengan responden dengan pengetahuan kurang. Hasil uji chi square $\mathrm{p}$ value $=0,001<0,05$ menunjukkan adanya hubungan yang bermakna antara pengetahuan dengan kepatuhan diet. Hasil penelitian ini sejalan yang dilakukan oleh Rizka Dwi Arini (2014) menunjukkan nilai $\mathrm{p}$ value $=0,027$ yang artinya lebih kecil dari $\alpha(0,05)$ bahwa terdapat hubungan tingkat pengetahuan penderita asam urat dengan kepatuhan diet rendah purin. Pengetahuan (kognitif) merupakan domain yang sangat penting untuk terbentuknya tindakan seseorang, dalam hal ini pengetahuan responden yang sudah baik, membuat mereka membatasi makan makanan yang mengandung tinggi purin tersebut.
Analisis mulitivariat digunakan untuk mengetahui keeratan hubungan antara variabel independen dan sub variabel independen, variabel counfounding terhadap variabel dependen. Analisis multivariat yang digunakan dalam penelitian ini adalah analisis regresi logistic dengan metode Backward Stepwise (Likelihood Ratio). Tahapan awal dengan memilih kandidat multivariat dengan melakukan seleksi variabel independen dan counfounding dengan melihat variabel yang memiliki nilai $\mathrm{p}<0.25$ dapat dijadikan kandidat dalam analisis multivariat.

Pemodelan tahap akhir didapatkan variabel yang paling berhubungan dengan kepatuhan diet, pemodelan disajikan sebagai berikut:

Tabel 9 Hasil analisis pemodelan terakhir regresi logistik dukungan informasional, penghargaan, instrumental, emosional, dan tingkat pengetahuan terhadap kepatuhan diet

\begin{tabular}{lccc}
\hline \multicolumn{1}{c}{ Variabel } & B & $\begin{array}{c}\text { Coefficients Beta } \\
(\text { Exp }(\mathbf{B}))\end{array}$ & P Value \\
\hline Dukungan Informasional & $-3,407$ & 0,033 & 0,001 \\
\hline Dukungan Instrumental & $-4,251$ & 0,014 & 0,001 \\
\hline Dukungan Emosional & $-1,390$ & 0,249 & 0,058 \\
\hline Pengetahuan & 1,686 & 5,399 & 0,054 \\
\hline
\end{tabular}

Tabel 9 menunjukkan proporsi hasil analisis multivariat didapatkan variabel yang paling berhubungan dengan kepatuhan diet adalah dukungan informasional, instrumental, emosional dan tingkat pengetahuan. Hubungan dukungan informasional dengan kepatuhan 
diet menunjukkan kekuatan yaitu 0,033. Hubungan dukungan instrumental dengan kepatuhan diet menunjukkan kekuatan yaitu 0,014 . Hubungan dukungan emosional dengan kepatuhan diet menunjukkan kekuatan yaitu 0,249 . Hubungan tingkat pengetahuan dengan kepatuhan diet menunjukkan kekuatan yaitu 5,399. Sehingga dari ke empat variabel tersebut tingkat pengetahuan yang memiliki hubungan yang paling dominan terhadap kepatuhan diet.

\section{KESIMPULAN}

Hasil penelitian yang dilakukan dilakukan di Puskesmas Benteng Kota Palopo, maka kesimpulan dalam penelitian ini yaitu sebagian besar peran perawat baik terhadap kepatuhan diet, sebagian besar tingkat pengetahuan dan dukungan keluarga tidak baik dan sebagian besar responden tidak patuh terhadap diet purin. Adanya hubungan pengetahuan, peran perawat dan dukungan keluarga terhadap kepatuhan diet pada lansia dengan gout atrithis di Puskesmas Benteng Kota Palopo. Variabel independen yang paling dominan terhadap kepatuhan diet adalah pengetahuan.

\section{REFERENSI}

Ariani RD, 2014, Hubungan Tingkat Pengetahuan Penderita Asam Urat Dengan Kepatuhan Diet Rendah Purin Di Karanganyar. Surakarta.

Arthritis Foundation. (2017). arthritis.org. from http ://www.arthritis.org/aboutarthritis/types/rheumatoid-arthritis/causes.php: arthritis.org
Ahmad. 2011. Cara Mudah Mencegah, Mengobati Asam Urat \& Hipertensi. Dinamika media: Jakarta.

Amalia SR 2017. Hubungan Dukungan Keluarga Dengan Kepatuhan Diet Asam Urat Di Puskesmas Gamping I. Yogyakarta.

Andry, Saryono, Arif. 2009. Analisis FaktorFaktor Yang Mempengaruhi Kadar Asam Urat Pada Pekerja Kantor di Desa Karang Turi Kecamatan Bumiayu Kabupaten Brebes. Jurnal Keperawatan Soedirman. Volume 4. No. 1. Tahun 2009. Diakses dari http://www. googlescholar.com pada tanggal 20 Januari 2019.

Arasti Dita Nisfiani.(2014). Hubungan Dukungan Keluarga Dengan Kepatuhan Diit Hipertensi Pada Lanjut Usia Di Desa Begajah Kecamatan Sukoharjo Kabupaten Sukoharjo Yogyakarta. Naskah Publikasi: Universitas Muhammadiyah Surakarta

Astuti, S. T. (2013). Faktor-faktor yang Mempengaruhi Kadar Asam Urat (Gout) pada Laki-laki Dewasa di RT 03 Simomulyo Baru Surabaya. Skripsi dipublikasikan. StikesWilliam Booth.

Ayuning Dewi. F. 2014. Pola Makan Lansia Penderita Asam Urat Di Posyandu Lansia Kelurahan Wonokromo Surabaya. Jurnal Ilmiah Kesehatan. Volume 7. No. 12. Tahun 2014. Diakses dari http://www.googlescholar.com pada tanggal 13 Desember 2018.

Brunner \& Suddarth. (2012). Buku Ajar Keperawatan Medikal- Bedah. Jakarta : EGC.

Bustan. (2007). Epidemiologi Penyakit Tidak Menular. Cet. 2. Jakarta: Rineka Cipta, 2007

Choi HK, Atkinson K, Karlson EW, Willet W, Curhan G. Alcohol intake and risk of incident gout in men: a prospective study. Lancet 2005. 
Damayanti (2015) Arthritis Rheumatoid Dan Penatalaksanaan Keperawatan. Nuha Medika. Yogyakarta

Dewi, Sofia. R. 2014. Buku Ajar Keperawatan Gerontik. Yogyakarta: CV Budi Utama.

Diantari, Ervi and Candra, Aryu. 2013.Pengaruh Asupan Purin Dan Cairan Terhadap Kadar Asam Urat Pada Wanita Usia 50-60 Tahun Di Kecamatan Gajah Mungkur, Semarang. Undergraduate thesis, Diponegoro University.

Didit dan Nety (2018), Hubungan Dukungan Keluarga Dengan Kepatuhan Diet Asam Urat Pada Lansia Di Posyandu Lansia Wilayah Kerja Puskesmas Wonokromo Surabaya

Efendi \& Makhfudli. (2009). Keperawatan Kesehatan Komunitas. Jakarta: Salemba Medika.

Fauziah A, 2014. Hubungan Pola Makan dengan Frekuensi Kekambuhan Nyeri Pasien Gout di Wilayah Kerja Puskesmas Kalisat. Jember

Fatmah. (2010). Merawat Manusia Lanjut Usia. Jakarta Timur: Trans Info Media.

Friedman, M. Marilyn. (2013). Buku Ajar Keperawatan Keluarga: Riset, Teori dan Praktik. Edisi 5. Jakarta. EGC.

Harnilawati. 2013. Konsep dan Proses Keperawatan Keluarga. Sulawesi Selatan: Pustaka As Salam.

Hidayat, A. (2007). Metode Penelitian Keperawatan dan Teknik Analisa Data. Jakarta: Salemba Medika.

Hidayat, Ismed. 2012. Kadar Asam Urat pada DM Tipe 2 yang Mengalami Stroke Iskemik. Tesis. Universitas Sumatera Utara.
Hidayat, R. (2009). Gout dan Hiperurisemia. Divisi Reumatologi Departemen Ilmu Penyakit Dalam, Fakultas Kedokteran Universitas Indonesia.

Juniarti, Citra, dkk, 2014, Hubungan Pengetahuan Dengan Kepatuhan Diet Pada Penderita Daibetes Mellitus yang dirawat di RSUD Labuang Baji Makassar, Volume 4, Nomor 1, 2014

Junaidi, Iskandar. 2013. Rematik \& Asam Urat.PT Gramedia Utama: Jakarta.

Kamaludin, Ridwan, et al, 2009, Analisi Faktor Yang Mempengaruhi Kepathan Asupan Cairan Pada Pasien Gagal Ginjal Kronik Dengan Hemodialisis DI RSUD Prof. Dr. Margono SoekarjoPurwokerto. Jurnal Keperawatan Soedirman, Volume. 4, Nomor 1, Maret 2009.

KEMENKES (Ed.). (2013). PMK No.25 ttg RAN Kesehatan Lanjut Usia Tahun 20162019. from PMK No.25 ttg RAN Kesehatan Lanjut Usia Tahun 2016-2019: kesga.kemkes.go.id

KEMENKES RI. (2014). Kementerian Kesehatan Republik Indonesia. from Info Datin - Kementerian Kesehatan Republik Indonesia:

www.depkes.go.id/folder/view/01/structurepublikasi-pusdatin-info-datin.html

Kementerian Kesehatan . (2016). kesga.kemkes.go.id/. Retrieved Februari 20, 2017 , from

http://kesga.kemkes.go.id/peraturan.php: http://kesga.kemkes.go.id/.

Mengenal Usia Lanjut dan Perawatannya. Jakarta: Salemba Medika.

Maryam. S. 2009. Mengenal Usia Lanjut dan Perawatannya. Jakarta: Salemba Medika. 
Murwani, A., \& Priyantari, W. (2010). Gerontik Konsep Dasar dan Asuhan Keperawatan Home Care dan Komunitas. Yokyakarta: Fitramaya.

Nisfiani a d, 2014. Hubungan Dukungan Keluarga Dengan Kepatuhan Diit Hipertensi Pada Lanjut Usia Di Desa Begajah Kecamatan Sukoharjo Kabupaten Sukoharjo. Surakarta.

Niven Neil. 2008. Psikologi Kesehatan Pengantar untuk Perawat \& Profesional Kesehatan Lain. Jakarta: EGC.

Notoatmodjo, S. 2007. Promosi Kesehatan dan Ilmu Perilaku. Jakarta: Rineka Cipta.

Notoatmodjo, S. 2012. Metodologi Penelitian Kesehatan. Jakarta: Rineka Cipta.

Noviyanti. (2015). Hidup Sehat Tanpa Asam Urat. Yogyakarta

Nursalam. 2006. Sistem Perkemihan. Jakarta: Salemba Medika.

Nugroho, W. (2012). Keperawatan Gerontik dan Geriatrik Edisi 3. Jakarta: Buku Kedokteran EGC.

Runtukahu, et, al, 2015, Analisis Faktor Yang Berhubungan Dengan Kepatuhan Melaksanakan Diet Pada Penderita Hipertensi Di Wilayah Kerja Puskesmas Wolaang Kecamatan Lawongan Timur. Ejournal Keperawatan Volume 3 Nomor 2, Mei 2015 Prihatiningsih, N. A. 2010. Hubungan Asupan Karbohidrat, Protein, Lemak, Air, Indeks Massa Tubuh dengan Kadar Asam Urat pada Laki-laki dengan Berat Badan Berlebih.

Purwaningsih, Tinah. 2010. Faktor-Faktor Risiko Hiperurisemia. Tesis. Universitas Diponegoro Semarang.
Potter \& Perry. 2005. Buku Ajar Fundamental Keperawatan: Konsep, Proses \& Praktik Volume 2. Jakarta: EGC.

Ridha Utami, dkk 2015. Hubungan Antara Tingkat Pengetahuan tentang Diet Rendah Purin dan Asupan Purin pada Wanita Usia di atas 45 Tahun di Puskesmas Kampung Bali. Jurnal Cerebellum. Volume 1 Nomor 4. November 2015. Fakultas Kedokteran UNTAN. Pontianak

RISKESDAS. (2013). Hasil RISKESDAS 2013 - Kementerian Kesehatan. from Hasil RISKESDAS 2013 - Kementerian Kesehatan: www.depkes.go.id/resources/download/genera 1/Hasil\%20Riskesdas\%202013.pdf

Rondonuwu R dkk, 2017. Hubungan Dukungan Keluarga Dengan Kepatuhan Mengkonsumsi Diet Rendah Purin Pada Penderita Gout Artrithis Di Desa Sea Satu Kecamatan Pineleng. Manado.

Saputra BI 2018, Hubungan Dukungan Keluarga Dengan Kepatuhan Diet Asam Urat Pada Lansia Penderita Gout Artritis Di Kacangan Giripurwo Purwosari Gunungkidul.Yogyakarta.

Setiadi. (2008). Konsep dan Proses Keperawatan Keluarga. Yogyakarta: Graha Ilmu.

Siti fadlilah dan adi sucipto, 2018. Analisis Faktor Yang Berhubungan Dengan Kadar Asam Urat Pada Masyarakat Dusun Demangan Wedomartani, Ngemplak. Sleman, Yogyakarta

Smeltzer, S.C \& Bare, B.G. 2002. Buku Ajar Keperawatan Medikal-Bedah Brunner \& Suddarth: Edisi 8 Vol 3. Jakarta: EGC.

Stanley. (2007). Buku Ajar Keperawatan Gerontik (Vol. Edisi 2). Jakarta: EGC. 
Sugiyono. (2012). Metode Penelitian Kuantitatif, Kualitatif, dan $R \& D$. Bandung: Alfabeta.

Triana, W., Mardijana, A., \& Rosita, D. (2016). Hubungan Intensitas Nyeri dengan Tingkat Kecemasan pada Pasien Artritis Reumatoid di RSD dr. Soebandi Kabupaten Jember. Artikel Ilmiah Hasil Penelitian Mahasiswa

Upoyo AS dkk, 2009, Analisis Faktor Faktor Yang Mempengaruhi Kadar Asam Urat Pada Pekerja Kantor Di Desa Karang Turi, Kecamatan Bumiayu, Kabupaten Brebes. Purwokerto.
Widuri, H. (2010). Asuhan Keperawatan pada Lanjut Usia Ditatanan Klinik. Jokjakarta: Fitramaya.

Wijayakusuma, H. (2007). Atasi Rematik Dan Asam Urat Ala Hembing. Jakarta: Puspa Suara.

Wortmann RL. Gout and hyperuricemia. Kelley`s Textbook of Rheumatlogy. 8th ed.Philadeplhia:Saunders;2001.p.1481-506. Wortmann RL. Gout and Other Disorders of Purine Metabolism. New York.2005, pp. 2079-2088.24 